\title{
THE ELIMINATION OF POLITICAL PARTIES IN CANADIAN CITIES
}

\author{
BY W. D. LIGHTHALL, K.C. \\ Montreal
}

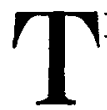

HE reason why I am called to address you to-day is that I come from a land whose people, in a true and profound sense, are part of your people, bone of your bone, sinew of your sinew, speech of your speech, spirit of your spirit; who, pervaded with the atmosphere of ideals and circumstances of this continent are, in the broad meaning, as American as you; and who, in their origin and growth, are in substance an overflow of the population of these United States. Before the revolution, New England people had begun to found what are now our provinces, and after the revolution the great basis of our population was laid by the loyalist refugees from every state, and by perhaps an equal number of others than loyalists who followed the rich opportunities of our territory. Even to-day one of the best and largest sources of our immigration is the stream of hundreds of thousands of American farmers who have taken up our western lands. I might go further, into a historical digression, and show that the British Empire, itself, had its origin among those same men of vision who gave birth to the idea of the united colonies. Both of those ideas began together before the revolution. It was our common American ancestors who dreamed them-the greatest political visions in the world.

It is, therefore, not surprising that our municipal institutions are essentially American-essentially on the same patterns as your own, with differences rather of experimentation and local accident than of structure. One of those local accidents is a very fortunate one-the elimination of political parties from our municipal politics. In this, perhaps, we may contribute something to your information, just as we constantly learn innumerable things from your municipal experience. Between Canada and the United States there is a great contrast in this matter.

We see with astonishment such things as Republican or Democratic control in the governments of your cities, tickets of candidates representing Republicans or Democrats, the evils of general party rancour introduced into local affairs, and too often we hear of the spoils system playing an only too important part in the result. In Canada, on the other hand, a party ticket in municipal affairs is unknown. A man's party opinions may gain him some votes, but merely in the same way as his association. with the masons or the independent order of moose have made him some incidental friends. The mere suggestion that party strife entered into 
the matter would arouse strong opposition among the voters and in most cases the candidate would be fain to publicly repudiate the suggestion in order not to lose his election. In short the introduction of party issues and shibboleths nearly everywhere in Canada is regarded as a dangerous and outlawed principle.

Just how this has come to be is somewhat difficult to determine. Certainly it was not so in our early municipal elections, eighty years ago, which were of a highly spicy and unladylike variety. Now, on the contrary, it is a fair statement that the elimination of party politics is a universally accepted sentiment. It is supported by all influential newspapers and strongly in favor with all classes of people. Its strength lies in the fact that it has become an attitude of mind, firmly fixed by habit. It certainly produces very beneficial results-a greater freedom and insistence upon the personal fitness of the candidate, a much reduced difficulty in finding really suitable candidates, and a sense that a candidate, once elected, is tied to no group of men, at least on party grounds. But the chief advantage is that it severs the municipal policy from all sorts of state and federal considerations. It thus enables a municipality to come before its legislature standing on the merits of its demands.

It is not to be gainsaid that several evils remain. Municipal politicians sometimes form groups among themselves, and sometimes municipalities are the victims of baneful influences and rapacious groups in the legislatures. But at least their difficulties are immensely simplified by the fact that the party question is nil. Internally, within municipalities, this freedom has made it easier to choose officials, and has everywhere made their standing a life tenure of their positions. It has also rendered it possible to have unanimity in councils over many measures and policies, based on untrammelled individual opinion of the aldermen, and it has enabled a municipality, when affected by pending legislation of the legislatures, to assemble to its aid the best men of all parties. The most striking and sweeping results have been rendered possible for the unions of municipalities in preventing legislative encroachments by corporations, and thefts of their rights and franchises by those charter sharks who infest all lobbies. The Union of Canadian Municipalities-the great general association of the cities and towns of Canada-has sometimes to fight the passing of some statute encroaching upon franchises or other rights of one of its numbers, or even of some municipality not in its membership, perhaps even some very weak and small municipality. In the federal parliament of Canada such bills are sometimes brought forward. But on every occasion where a fair case exists, the union counts on untrammelled combination of all the best elements of both parties, and invariably obtains a victory, in which the name of either party is scarcely so much as mentioned. The same process goes on before the provincial legislatures (corresponding to those of your states), before which the 
provincial branches of the union take up similar matters, and whatever difficulties they may have with commercial groups or chartersharks, there is almost invariably the same absence of the suggestion of party. It is unnecessary to catalogue all the other beneficial results.

Now, from the modest acquaintance I have with American municipal affairs, based mainly on a long association with the National Municipal League and other American municipal bodies, and also partly on a constant reading of the newspapers, I know that many of your municipal experts sometimes envy us this advantage, and wonder how it can be introduced in the United States, and added to your long list of important. municipal triumphs.

Let me make only two remarks on that question,-First, that, whatever be the method, the object should be to attain a habit of public mind against the continuance of the party system. In Canada it rests upon a habit of public mind acquired during the past half century, and favored no. doubt by the fact that our party methods have never attained such completeness of system as your own. They have never come down to such refinements as your party tickets. The second point is that, whether the process be long or short, simple or difficult,- -and there is no doubt it will be difficult, - I have absolute confidence in the American people, in their ability to achieve any idea. The elimination of party politics will come to you as it has to us, sometime,-and within a reasonable time. The struggle for it is not a hopeless one, and ought to be pursued systematically with optimism, and having as its set purpose the gradual creation of the necessary habit of public thought.

As the representative here of the Union of Canadian Municipalities, I bring you the profound congratulations and the absolute sympathy of the Canadian people in all your splendid work. 